\title{
New Reading Activities
}

\author{
Anna Bąk-Średnicka ${ }^{1, *}$ \\ ${ }^{1}$ Department of Humanities, The State School of Higher Education in Sandomierz, Poland \\ *Correspondence: Department of Humanities, The State School of Higher Education in Sandomierz, Poland \\ E-mail: annabak18@poczta.onet.pl
}

Received: December 28, 2012 Accepted: January 15, $2013 \quad$ Online Published: March 13, 2013

doi:10.5430/wjel.v3n1p78 URL: http://dx.doi.org/10.5430/wjel.v3n1p78

\begin{abstract}
The article elaborates on seven abstract systems of discourse analysis within the spectrum of linguistics. The analyses uncover those elements in an authentic text which are responsible for its cohesion and coherence. The descriptions have been illustrated with 11 exercises with a view to employing them as new teaching activities. It is assumed that their considerable potential can enrich the existing repertoire of follow-text activities in foreign language textbooks.
\end{abstract}

Keywords: reading; comprehension activities; EFL classroom

\section{Introduction}

This article grew out of concern that too often we perceive reading in the classroom as a pure passive activity. The common knowledge about the inactive, receptive nature of reading can directly lead to oversimplifications of its role and place in the educational process. As a result of the above, it can be automatically assumed that the task of the reader is to merely interpret the literal meanings encoded in a piece of writing. As a consequence of the attitude, combined with overdependence on standard teaching materials which 'will do the job for us', many of us do not know how to 'take the bull by the horns' and prepare deeply inspiring reading lessons. We have to take into account the fact that sometimes the batteries of activities that accompany articles in course books are predictable and therefore demotivating for so many of our students who study more than just one foreign language. Too often lessons based on such activities produce for them an unbearable ennui.

Another thing which influenced the choice of the topic is that there is still a lot to do to exploit the true potential of reading aloud both as a technique and a language skill. There is some theory behind the intuition that tells us not to disregard oral reading as sheer professional incompetence. Similarly, some of us too rarely draw their learners' attention to the lexical patterns that stand for lexical and grammatical unity of texts. As a consequence learners do not develop useful strategies which can speed successful reading as well as writing and contribute to their success at exams. Also, the negligence of practical approach to metaphorical concepts that are 'alive and kicking' in authentic materials simply minimizes students' chances of becoming independent and competent foreign language users.

The basic idea of the article is that we encourage teachers to go beyond and beneath of what we have already learnt and adopt new ways of working with texts. It is believed that the key to success is to offer our students more and more techniques which keep up with the pace of and reflect the changes in discourse analysis as such. The direct inspiration of the approaches developed here came from purely academic sources. The core of the discussion are following seven areas:

1) the place of miscue analysis in practicing oral reading skill,

2) examining the distribution patterns of cohesion within an entire text in order to discover some generalizations,

3) discussing 'signalling mechanisms' of the Problem-Solution structure of texts,

4) describing the structure of semantic relationship by means of n-dimensional diagrams,

5) analysing texts via the triad, a minimal unit of interaction consisting up to three elements of structure,

6) diagramming a text according to Mann and Thompson's rhetorical structure theory,

7) developing metaphoric competence. 


\section{Why not get Your Students Involved in the Miscue Analysis Process}

Foreign language teachers are generally advised against introducing the technique and skill of reading aloud in the classroom. However, the reasons are related to more complex problems of ill-prepared and badly thought-over lessons. If reading aloud is a routine classroom activity rather than a pre-planned and purposeful task, than we can expect that its full potential may never be recognized and exploited.

The inspiration to recognize the strengths of reading aloud comes from a research instrument designed by Kenneth Goodman: Taxonomy of Oral Reading Miscues. The tool enables us to analyze graphophonemic, semantic and syntactic errors and mistakes as well as our students' strategies for dealing with miscues.

The model has the following structure:

- the teacher instructs her student to read aloud an unfamiliar (and difficult) text, and be ready to retell it,

- the student is asked to retell the story to the teacher who can use guide questions to elicit responses.

- the reading and retelling are recorded.

- the data can then be analyzed using adaptations of the Goodman Taxonomy.

There have been some interesting attempts to adapt the studies into foreign language classroom. For example, the project proposed by Rigg (1998) stresses three implications from the Miscue-ESL Project for foreign language teachers. First of all, by allowing the student to read without interfering the teacher enables the reader to develop reading strategies. Secondly, retelling the previously read text trains students for comprehension. Thirdly, oral reading is 'a window' into how the reading process functions (pp. 206-219).

Similarly, the project proposed by Hatch and Brown, (1998) suggests recording a group of students reading aloud a passage in the target language. The analysis of the recordings involves: identifying the mistakes caused by the grammatical structure, the mistakes caused by mistaking one word for a similar looking word, the mistakes caused by native language influence, as well as the influence of form on how students identify words in context (p. 380).

Generally speaking, the analysis should enable the teacher to determine the number of miscues per a hundred words (MPHW). Then the number can be compared against the percentage of miscues that the reader corrects and the percentage of miscues which are syntactically and semantically acceptable. In this way the teacher can develop information about each individual student as well as groups. Last but not least is the fact that we can engage digital students into recording the texts on their mobiles and sending them to the teacher's e-mail box.

There are possible other modifications of the miscue analysis method. A case in point is an experiment carried out by a secondary-year-English philology student and an experienced secondary school teacher in one. She conducted the study among a group of ten students at a lower-secondary school and presented the result as a final English methodology project. After the recording session each student received his or her detailed list of miscue words. Additionally, the teacher made a list of most frequent miscues in the group. In her conclusions the teacher admitted that the results of miscue analysis are a valuable clue for her about how particular students deal with a text that is slightly above their language level. Satisfying results can encourage both the teacher and her students to reach for more demanding texts. What is more, the teacher revealed that her students found the task of recording one another refreshing and good fun, (e.g. Makowska, 2010).

Thus apart from the unquestioned usefulness of the data for the teacher to reflect upon; the task has some new and attractive elements for students themselves, such as: recording their own voice, singling out and naming different types of errors and preparing a typescript which can be compared with earlier versions by the students themselves. So, by applying modified versions of Kenneth Goodman's Taxonomy of Oral Reading Miscues, the teacher individualizes the didactic process in the classroom. It has been observed that students are vividly interested in how well they performed, which is a step forward towards learners autonomy and responsibility for their own language development.

\section{Examining the Distribution Patterns of Cohesion within an Entire Text In Order To Discover Some Generalizations}

Your students with mathematical-logical and linguistics intelligences may welcome a change in simple decoding pedagogic texts during English lessons. The idea here is to develop their discourse-processing skill (McCarthy, 1995, p. 54) and teach them some facts about the notions of discourse pattern of English texts. As teachers we realize that reading is an interactive process and in order to semanticize, interpret and evaluate, (Dakowska, 2005, pp. 193-194) a 
piece of text, our students need to actively participate in it. Therefore, what follows are examples when search read (Harri-Augstein and Thomas, 1996) enables students to:

- understand that some words and cohesive devices play essential roles in organizing discourse (e.g. Urbanowá, 2007),

- identify central and marginal sentences and uncover topics (e.g. Langhoff, 2010).

\subsection{Principles of the Theory}

In order to realize the potential of Dr Hoey's (1996) analysis for teaching English as a foreign language, and for perceiving the reader's role as a creative one; let's look at the principles of the theory. Cohesion stands for a text grammatical and lexical unity. The nature of text structure is examined through analysing the following repetition links that cohere with one another:

- lexical repetition (simple and complex)

- $\quad$ araphrase (mutual and partial)

- antonyms,

- synonyms,

- substitution

- co-reference

- ellipsis,

- conjunction.

We can gradually understand what stands for an authentic text logical and grammatical unity. For the sake of simplicity, examples are illustrated by means of a five-sentence-long authentic text taken from THE GUARDIAN WEEKLY.

\section{FOSSIL SKULL SHOWS SPLIT IN PRIMATE'S LINEAGE}

1) A fossilized skull has been unearthed that sheds light on the evolutionary origins of apes, including humans.

2) The creature was no bigger than a baboon and lived in a warm, damp forest near what is now the Red Sea in western Saudi Arabia, between $28 \mathrm{~m}$ and $29 \mathrm{~m}$ years ago.

3) The remains of the primate, named Saadanius hijazensis, which include a partial skull and teeth, were recovered from ironstone sediment during an expedition in February 2009.

4) The discovery, reported in Nature, is being hailed as very significant because it illuminates a moment in evolution when ancient primates split into two separate lineages.

5) One group of primates gave rise to the Old World monkeys, which include baboons, while the other led to the great apes and, ultimately, Homo sapiens.

THE GUARDIAN WEEKLY, 23.07 .10 (p. 31)

Exercise 1. Study the five sentences and compare them with each other, looking for repetition links. Then present the results in Figure 1. 
(1)

\begin{tabular}{|c|c|c|c|}
\hline $\begin{array}{l}\text { a fossilized skull - the creature } \\
\text { apes }- \text { a baboon }\end{array}$ & (2) & & \\
\hline $\begin{array}{l}\text { unearthed - recovered } \\
\text { apes - the primate } \\
\text { a skull - a skull } \\
\text { fossilized - ironstone } \\
\text { damp - sediment } \\
\text { humans - Saadanius hijazensis } \\
\text { including - include }\end{array}$ & $\begin{array}{l}\text { the creature } \text { - the remains } \\
\text { a baboon - the primate } \\
\text { years }-2009\end{array}$ & (3) & \\
\hline $\begin{array}{l}\text { the discovery - a skull } \\
\text { evolutionary - evolution } \\
\text { apes - primates } \\
\text { sheds light - illuminates } \\
\text { including - separate }\end{array}$ & the creature - primates & $\begin{array}{l}\text { the remains - the discovery } \\
\text { primate - primates }\end{array}$ & (4) \\
\hline $\begin{array}{l}\text { apes - primates } \\
\text { humans - Homo sapiens } \\
\text { origins - gave rise } \\
\text { including - include }\end{array}$ & $\begin{array}{l}\text { bigger - great } \\
\text { creature - primates } \\
\text { baboon - baboons }\end{array}$ & $\begin{array}{l}\text { primate - primates } \\
\text { Saadanius hijazensis - Homo } \\
\text { sapiens } \\
\text { include - include }\end{array}$ & $\begin{array}{l}\text { the discovery - Homo sapiens } \\
\text { old World - ancient } \\
\text { primates - primates } \\
\text { lineages - group } \\
\text { two - one }\end{array}$ \\
\hline
\end{tabular}

Figure 1: Patterns of Repetition in FOSSIL SKULL SHOWS SPLIT IN PRIMATE'S LINEAGE

Exercise 2. Fill the 10 cells in Figure 2 with numbers that stand for the repetitions and lexicalizations.

(1)

(2)

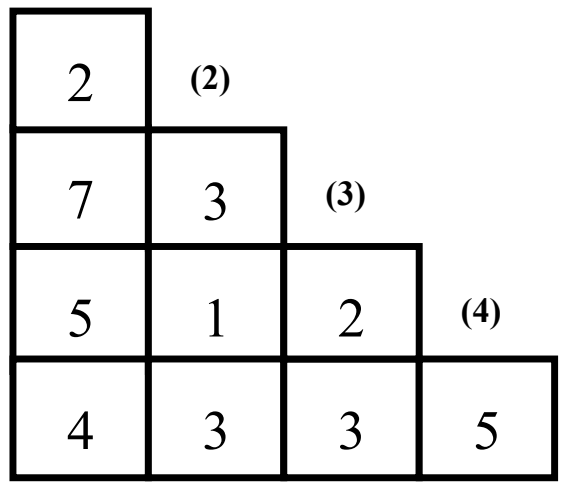

Figure 2: Matrix Representing the Full Complexity of the Lexical Patterning in the Text FOSSIL SKULL SHOWS SPLIT IN PRIMATE'S LINEAGE 
Exercise 3. Create sentence co-ordinates.

1. $(0,3)$

2. $(0,2)$

3. $(2,1)$

4. $\quad(1,1)$

5. $(4,0)$

Figure 3: Sentence co-ordinates in the text FOSSIL SKULL SHOWS SPLIT IN PRIMATE'S LINEAGE. The bracketed figures stand for the number of bonds (more than three links) that each of the 5 sentences forms with its previous and subsequent sentence

The central sentence of the text is sentence 5:

One group of primates gave rise to the Old World monkeys, which include baboons, while the other led to the great apes and, ultimately, Homo sapiens.

The marginal sentences of the text are sentences 2 and 4 :

The creature was no bigger than a baboon and lived in a warm, damp forest near what is now the Red Sea in western Saudi Arabia, between 28m and 29m years ago. The discovery, reported in Nature, is being hailed as very significant because it illuminates a moment in evolution when ancient primates split into two separate lineages.

A similar analysis by Urbanowá, (2007) encourages teachers to use discourse patterns and lexical cohesion to help students discover certain regularities within news reports in English. In fact, she presents a simplified approach to the analysis of newspaper reports in order to uncover some regularities and map the distribution of lexical cohesion. The author suggests that a teacher should make students aware of the fact that "a comprehensible answer to a question may not be found in one portion of text since a principle of cyclic ordering may come into play" (pp. 137- 143). Therefore, the teacher may introduce elements of the analysis of lexical cohesion proposed by Hoey (1991) and teach students how to get the gist of a news report. The presented type of analysis can help a teacher "immediately see how frequently and in which sentence a particular item appears, which enables him to decide whether the item is important to get to the gist of the article and worth learning" (Urbanowá, 2007, p. 142). Figure 4 presents the quantity of links, whereas Figure 5 shows the quality of the links.

\section{FOSSIL SKULL SHOWS SPLIT IN PRIMATE'S LINEAGE}

1) A fossilized skull has been unearthed that sheds light on the evolutionary origins of apes, including humans.

2) The creature was no bigger than a baboon and lived in a warm, damp forest near what is now the Red Sea in western Saudi Arabia, between $28 \mathrm{~m}$ and $29 \mathrm{~m}$ years ago.

3) The remains of the primate, named Saadanius hijazensis, which include a partial skull and teeth, were recovered from ironstone sediment during an expedition in February 2009.

4) The discovery, reported in Nature, is being hailed as very significant because it illuminates a moment in evolution when ancient primates split into two separate lineages.

5) One group of primates gave rise to the Old World monkeys, which include baboons, while the other led to the great apes and, ultimately, Homo sapiens.

THE GUARDIAN WEEKLY, 23.07 .10 (p. 31) 


\begin{tabular}{lccccc}
\hline & S1 & S2 & S3 & S4 & S5 \\
\hline Fossilized & $\mathrm{V}$ & & $\mathrm{V}$ & & \\
Skull & $\mathrm{V}$ & & $\mathrm{V}$ & & \\
Unearthed & $\mathrm{V}$ & & $\mathrm{V}$ & & \\
Sheds light & $\mathrm{V}$ & & & $\mathrm{V}$ & \\
Evolutionary & $\mathrm{V}$ & & & $\mathrm{V}$ & \\
Origins & $\mathrm{V}$ & & & & $\mathrm{V}$ \\
Apes & $\mathrm{V}$ & $\mathrm{V}$ & $\mathrm{V}$ & $\mathrm{V}$ & $\mathrm{V}$ \\
Including & $\mathrm{V}$ & & $\mathrm{V}$ & & $\mathrm{V}$ \\
Humans & $\mathrm{V}$ & $\mathrm{V}$ & $\mathrm{V}$ & $\mathrm{V}$ & $\mathrm{V}$ \\
Bigger & $\mathrm{V}$ & & & & $\mathrm{V}$ \\
Damp & & $\mathrm{V}$ & $\mathrm{V}$ & & \\
Years & & $\mathrm{V}$ & $\mathrm{V}$ & & \\
Remains & & & $\mathrm{V}$ & $\mathrm{V}$ & \\
Ancient & & & & $\mathrm{V}$ & $\mathrm{V}$ \\
Lineages & & & & $\mathrm{V}$ & $\mathrm{V}$ \\
Two & $\mathrm{V}$ & & & & $\mathrm{V}$
\end{tabular}

Figure 4: The Quantity of Words in FOSSIL SKULL SHOWS SPLIT IN PRIMATE'S LINEAGE. S Stands for Sentences 1-5

\begin{tabular}{ll}
\hline Fossilized & ironstone \\
Skull & skull \\
Unearthed & recovered \\
Sheds light & illuminates \\
Evolutionary & evolution \\
Origins & gave rise \\
Apes & baboon, primate, apes \\
Including & include \\
Humans & creature, Saadanius hijazensis, primates, Homo sapiens \\
Bigger & great \\
Damp & sediment \\
Years & 2009 \\
Remains & discovery \\
Ancient & Old World \\
Lineages & group \\
Two & one
\end{tabular}

Figure 5: The Quality of Words in FOSSIL SKULL SHOWS SPLIT IN PRIMATE'S LINEAGE

The key items of the text: apes, humans.

Decoding authentic texts does not have to be limited only to advanced foreign language readers. On the contrary, in order to motivate our students who are at lower-intermediate level we can reach for any articles which correspond with their interests. In fact, the additional materials we reach for are limited only by our own imagination. The above is possible thanks to the fact that students can read selectively, (i.e. do not bother about some unknown words, phrases or even sentences). In other words, the instructions on how to recognize lexical items responsible for cohesion and coherence in an article sensitize our students to recognize them and become efficient readers of even advanced texts. 


\section{Discussing 'signalling mechanisms' of the Problem-Solution Structure of Texts}

Another way of structure analysis proposed by Hoey (1998) improves students' communicative skills mainly by "demonstrating to them not only the typical Problem-Solution structure but also the signalling system available to make clear the structure of whatever they write" (pp. 26-45). In the example we aim to identify functional units (Situation, Problem, Response and Evaluation). Hoey (1998) claims that the first full sentence of each functional unit forms a "reasonable skeleton" of the text (p. 43). First let's decide which sentences represent the four functional units of FOSSIL SKULL SHOWS SPLIT IN PRIMATE'S LINEAGE.

\section{FOSSIL SKULL SHOWS SPLIT IN PRIMATE'S LINEAGE}

1a) A fossilized skull has been unearthed $1 \mathrm{~b}$ ) that sheds light on the evolutionary origins of apes, including humans. 2a) The creature was no bigger than a baboon $2 b$ ) and lived in a warm, damp forest near 2c) what is now the Red Sea in western Saudi Arabia, 2d) between 28m and 29m years ago. 3a) The remains of the primate, 3b) named Saadanius hijazensis, 3c) which include a partial skull and teeth, 3d) were recovered from ironstone sediment 3e) during an expedition in February 2009. 4a) The discovery, 4b) reported in Nature, is being hailed 4c) because it illuminates a moment in evolution 4d) when ancient primates split into two separate lineages. 5a) One group of primates gave rise to the Old World monkeys, 5b) which include baboons, $5 \mathrm{c}$ ) while the other led to the great apes and, ultimately, Homo sapiens.

THE GUARDIAN WEEKLY, 23.07 .10 (p. 31)

Exercise 4. Formulate Basic Structure of the text. Choose the first full sentence of each functional unit to form a "reasonable skeleton" of the text.

\section{BASIC STRUCTURE}

Situation: 1a, 2, 3, 4b

Problem: 4d

Response: 5

Evaluation: 1b, 4a, 4c

\section{"The skeleton"}

One group of primates gave rise to the Old World monkeys, which include baboons, while the other led to the great apes and, ultimately, Homo sapiens.

Exercise 5. Single out lexical signalling.

Next we can identify lexical items signalling the Situation-Problem-Solution-Evaluation design.

Situation: skull, unearthed, origins, apes

Problem: partial, skull, teeth, lineages

Response: creature, the Red Sea, 28-9m years ago, Saadanius hijazensis, expedition, 2009, Old World monkeys, apes

Evaluation: discovery, significant, evolution

Exercise 6. Write missing questions in the dialogue test.

Another technique of uncovering the underlying text structure is to project the text into question-and-answer dialogue.

A: What has been unearthed?

B: A fossilized skull.

A: Why is it significant?

B: It sheds light on the evolutionary origins of apes, including humans.

A: How big was the creature?

B: The creature was no bigger than a baboon.

A: Where did it live?

B: It lived in a warm, damp forest near what is now the Red Sea in western Saudi Arabia.

A: When did it live?

B: Between $28 \mathrm{~m}$ and $29 \mathrm{~m}$ years ago 
A: How is the primate named?

B: Saadanius hijazensis.

A: What do the primate remains include?

B: A partial skull and teeth.

A: Where were the remains recovered from?

B: From ironstone sediment.

A: When were they recovered?

B: During an expedition in February 2009.

A: Where was the discovery reported?

B: In Nature.

A: How was it hailed?

B: As very significant.

A: Why was it hailed as very significant?

B: Because it illuminates a moment in evolution.

A: What moment in evolution does it illuminate?

B: When ancient primates split into two separate lineages.

A: What did the lineages give rise to?

B: One group of primates gave rise to the Old World monkeys.

A: What monkeys did it include?

B: Baboons.

A: What did the other group lead to?

B: The other led to the great apes and, ultimately, Homo sapiens.

\section{Three Types of Information Structure}

This approach to text analysis arose out of the problem of non-linearity of the structure of information which has to be realized in linear texts. Johns (1998, p. 105) describes three types of information structure of the text which can be diagrammed into three n-dimensional graphs (as presented in Figure 6):

- the tree diagram

- the matrix

- the flow-chart
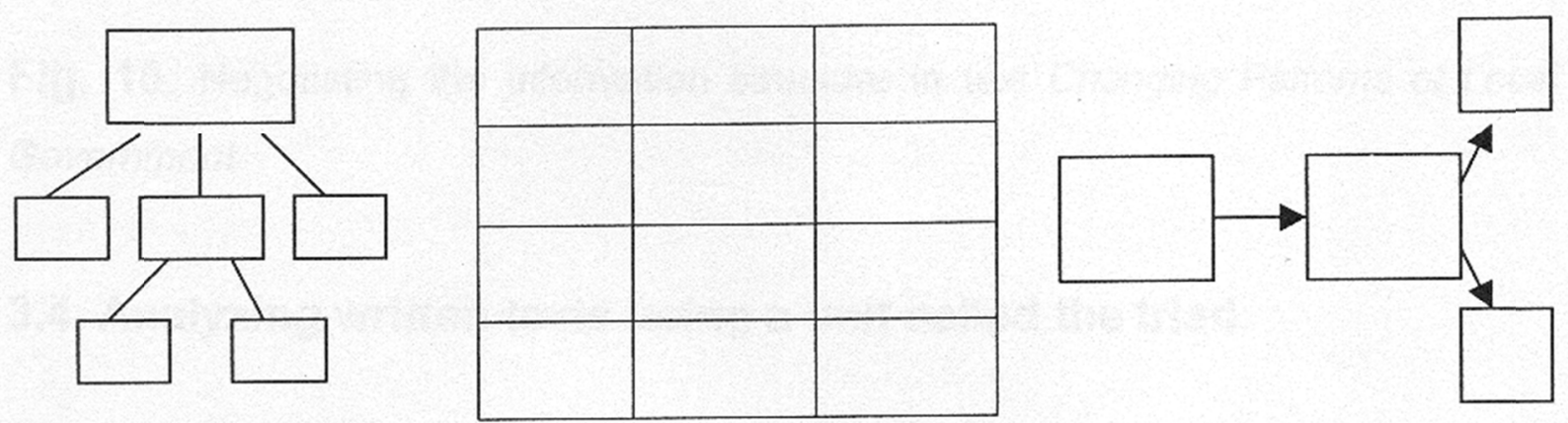

Figure 6: Three Main Types of Information Structure: Tree-diagram, Matrix and Flow-chart, (Johns, 1998, p. 105)

Exercise 7. Structure the text FOSSIL SKULL SHOWS SPLIT IN PRIMATE'S LINEAGE in the proper diagram. 
A fossilized skull has been unearthed that sheds light on the evolutionary origins of apes, including humans.

\begin{tabular}{|c|c|c|c|}
\hline $\begin{array}{l}\text { The creature was } \\
\text { no bigger than a } \\
\text { baboon and } \\
\text { lived in a warm, } \\
\text { damp forest near } \\
\text { what is now the } \\
\text { Red Sea in } \\
\text { western Saudi } \\
\text { Arabia, between } \\
28 \mathrm{~m} \text { and } 29 \mathrm{~m} \\
\text { years ago. }\end{array}$ & $\begin{array}{l}\text { The remains of the } \\
\text { primate, named } \\
\text { Saadanius } \\
\text { hijazensis, which } \\
\text { include a partial } \\
\text { skull and teeth, were } \\
\text { recovered from } \\
\text { ironstone sediment } \\
\text { during an expedition } \\
\text { in February 2009. }\end{array}$ & $\begin{array}{l}\text { The discovery, } \\
\text { reported in Nature, } \\
\text { is being hailed as } \\
\text { very significant } \\
\text { because } \\
\text { illuminates } \\
\text { moment } \\
\text { evolution in } \\
\text { ancient primates } \\
\text { split into two } \\
\text { separate lineages. }\end{array}$ & $\begin{array}{l}\text { while the } \\
\text { other led to } \\
\text { the great apes } \\
\text { and, } \\
\text { ultimately, } \\
\text { Homo } \\
\text { sapiens. }\end{array}$ \\
\hline
\end{tabular}

Figure 7: The Information Structure for FOSSIL SKULL SHOWS SPLIT IN PRIMATE'S LINEAGE

\section{Analysing Written Texts Using a Unit Called the Triad}

The key issue of the theory is the belief that there are three part structures in discourse and the third element, which can be predicted is either obligatory or optional feedback. The triad consists of three turns (Tn):

- $\quad$ lead (L)

- follow (F), and

- valuate $(\mathrm{V})$.

Triads are realized through sentences and they can exhibit unrestricted turns on condition that the sequence LF (lead, follow) are repeated and V (valuate) is final, (Bolivar, 1998, pp. 280-283). With regard to position and function, there are three kinds of triads $(\mathrm{Td})$ :

- $\quad$ Situation (S),

- Development (D), and

- Recommendation (R).

A larger unit combined of several triads is called movement $(\mathrm{Mv})$, which again combines with other movements and forms 'the largest unit at the highest rank' termed as artefact.

There are three types of movements:

- Type A referring to the actual and past world,

- Type B referring to possibilities (what might be), and

- Type $\mathrm{C}$ referring to the world that should be.

Figure 8 presents a structured version of the Triad. 


\section{O V E M E N T}

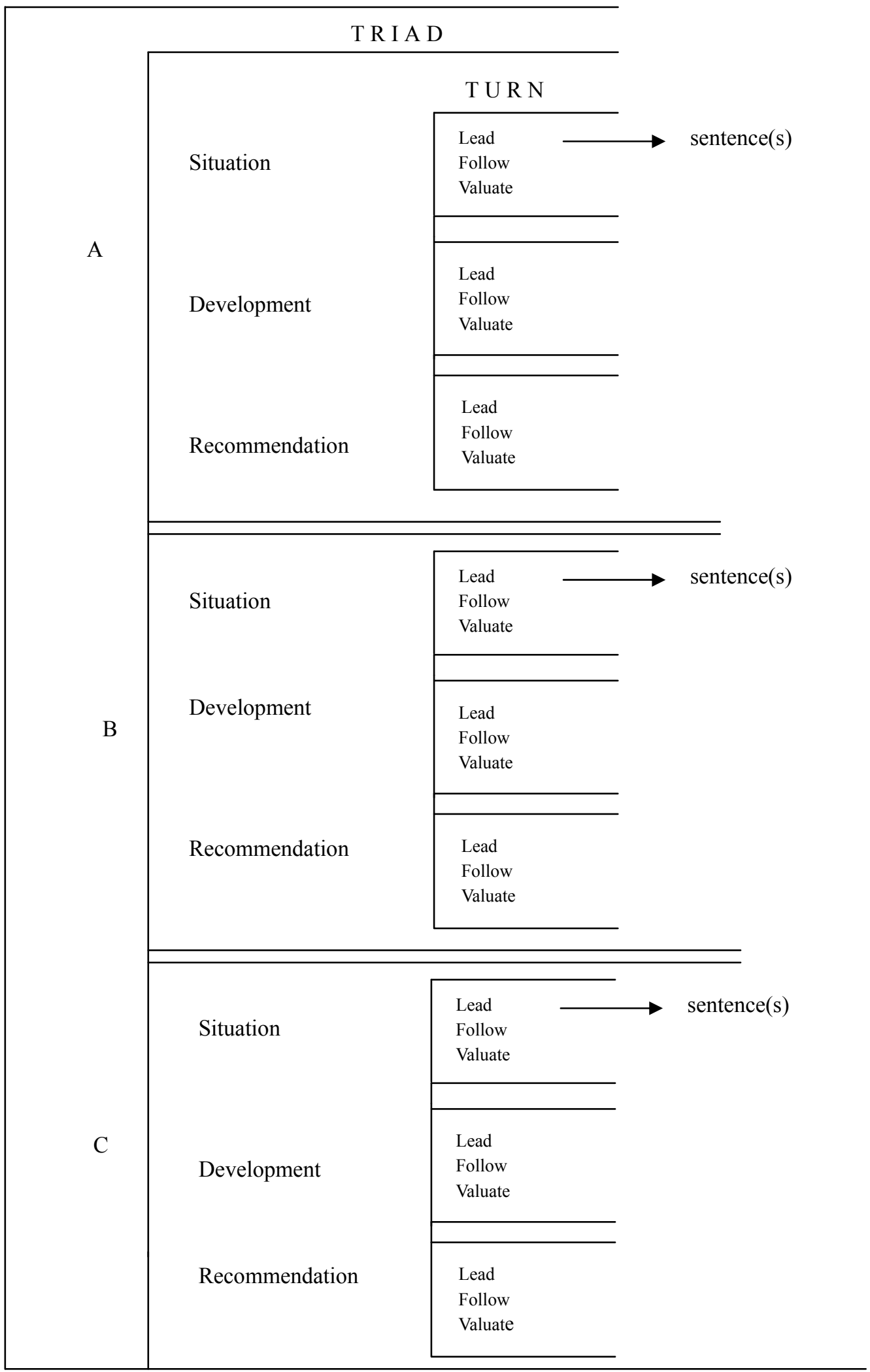

Figure 8: A Structured Version of the TRIAD 
Exercise 8. Analyse the text using a triad.

\begin{tabular}{|c|c|c|c|}
\hline Mov. & $\mathrm{Td}$ & Tn & S \\
\hline \multirow[t]{3}{*}{$\overline{\mathrm{A}}$} & $\bar{S}$ & $\mathrm{~L}$ & $\begin{array}{l}\text { 1. A fossilized skull has been unearthed that } \\
\text { sheds light on the evolutionary origins of } \\
\text { apes, including humans. }\end{array}$ \\
\hline & & $\mathrm{F}$ & $\begin{array}{l}\text { 2. The creature was no bigger than a baboon } \\
\text { and lived in a warm, damp forest near } \\
\text { what is now the Red Sea in western Saudi } \\
\text { Arabia, between } 28 \mathrm{~m} \text { and } 29 \text { m years ago. } \\
\text { 3. The remains of the primate, named } \\
\text { Saadanius hijazensis, which include a } \\
\text { partial skull and teeth, were recovered } \\
\text { from ironstone sediment during an } \\
\text { expedition in February } 2009 \text {. }\end{array}$ \\
\hline & & V & $\begin{array}{l}\text { 4. The discovery, reported in Nature, is being } \\
\text { hailed as very significant because it } \\
\text { illuminates a moment in evolution when } \\
\text { ancient primates split into two separate } \\
\text { lineages. } \\
\text { 5. One group of primates gave rise to the Old } \\
\text { World monkeys, which include baboons, } \\
\text { while the other led to the great apes and, } \\
\text { ultimately, Homo sapiens. }\end{array}$ \\
\hline
\end{tabular}

Figure 9: A Structured Version of FOSSIL SKULL SHOWS SPLIT IN PRIMATE'S LINEAGE

\section{Rhetorical Structure Theory Diagram}

RST analysis describes a text as composed of text portions. Authors use a number of relations (Figure 11) in order to achieve an EFFECT. The order of the portions of the text is not fixed, yet Fries, (1998) has observed that: "writers use position at the end of the clause to indicate the newsworthy information to their reader, and the beginning of their clauses to orient their readers to the message which will come in the rest of the clause" (pp. 233-234). Similarly, Hatch (1994) states that "the preferred placement of the new and the old information is following: new information is more often in final position (RHEME), whereas old one in initial position (THEME)" (pp. 189-192).

Exercise 9. Underline the THEME of the clause with a single line, and the RHEME of the clause with a double line.

Key:

Capital letters: paragraphs

Arabic numbers: sentences

Small letters: clauses within a sentence

\section{A}

1a) A fossilized skull has been unearthed that $1 \mathrm{~b}$ ) sheds light on the evolutionary origins of apes, including humans. 2a) The creature was no bigger than a baboon $2 \mathrm{~b}$ ) and lived in a warm, damp forest near 2c) what is now the Red Sea in western Saudi Arabia, 2d) between 28m and 29m years ago. 3a) The remains of the primate, named Saadanius hijazensis, 3b) which include a partial skull and teeth, 3c) were recovered from ironstone sediment 3d) during an expedition in February 2009.4a) The discovery, 4b) reported in Nature, is being hailed 4c) because it illuminates a moment in evolution 4d) when ancient primates split into two separate lineages. $5 \mathrm{a})$ One group of primates gave rise to the Old World monkeys, $5 \mathrm{~b}$ ) which include baboons, $5 \mathrm{c}$ ) while the other led to the great apes and, ultimately, Homo sapiens.

Exercise 10. Decide on types of relations (Figure 11) among clauses and sentences used by the author of FOSSIL 
SKULL SHOWS SPLIT IN PRIMATE'S LINEAGE in order to achieve coherence.

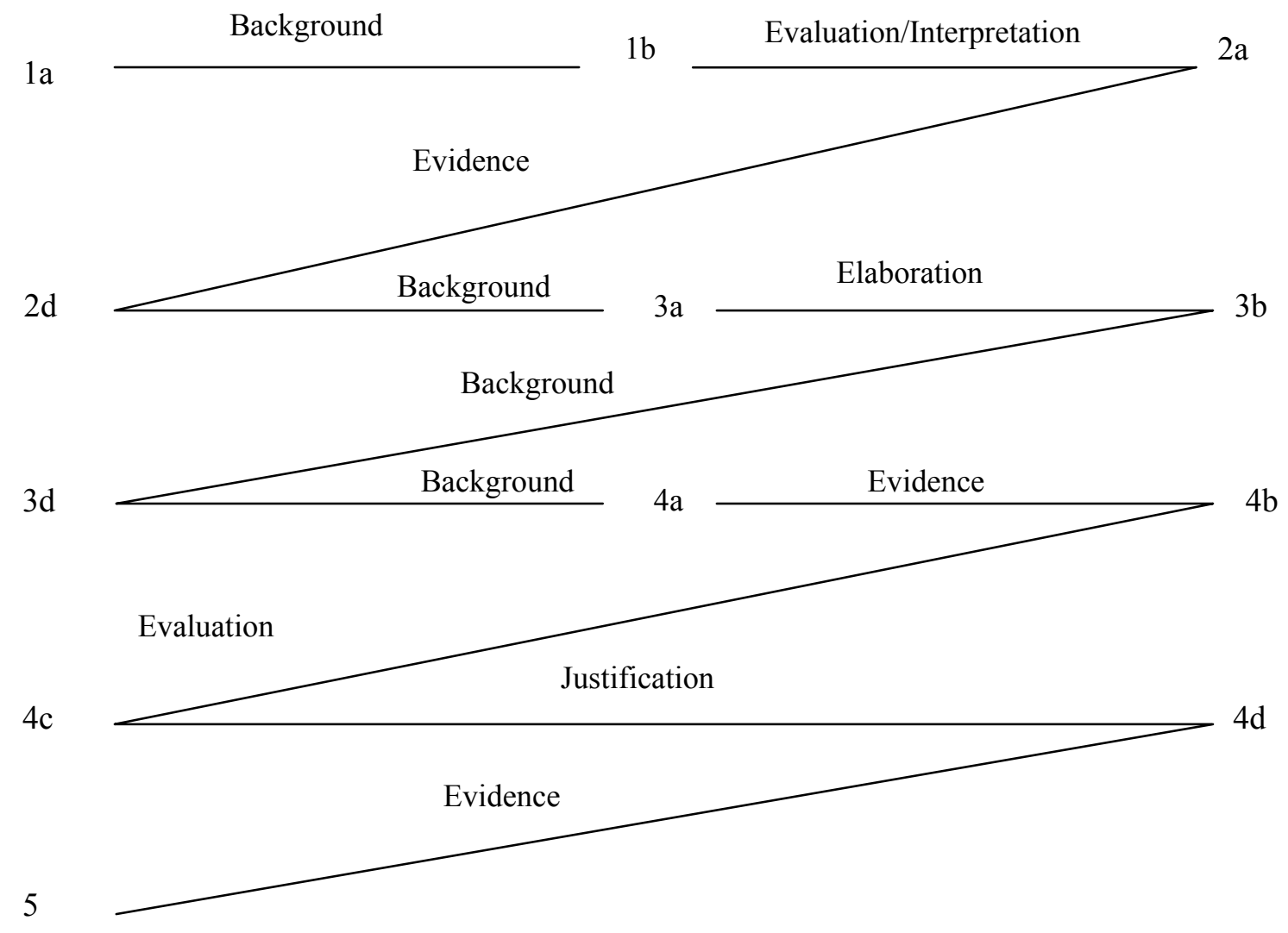

Figure 10: Types of Relations among Clauses and Sentences Used by the Author of FOSSIL SKULL SHOWS SPLIT IN PRIMATE'S LINEAGE

Circumstance
Solutionhood
Elaboration
Antithesis and concession
$\quad$ Antithesis
$\quad$ Concessions
Background
Enablement and motivation
$\quad$ Enablement
$\quad$ Motivation
Evidence and justify
Evidence
Justify

\author{
Relations of cause \\ Volitional cause \\ Nonvolitional cause \\ Volitional result \\ Nonvolitional result \\ Purpose \\ Condition and otherwise \\ Condition \\ Otherwise \\ Interpretation and evaluation \\ Interpretation \\ Evaluation \\ Resentment and summary \\ Resentment \\ Summary \\ Other relations \\ Sequence \\ Contrast
}

Figure 11: The List of the Types of Relations Used by Authors in Order to Achieve an Effect (Hatch, 1994, pp. 189-190) 


\section{A Practical Approach to Metaphorical Concepts}

Aristotle believed that "one had to be a genius in order to use a metaphor properly" (Mahon, 1999, p. 69). It is strongly believed that we can take advantage of written texts by analyzing their metaphors and in this way contribute to developing our students' metaphorical competence. The competence is indispensable as "abstract thought is only possible through the use of metaphor" (Malmkjær, 2010, p. 365). Let us focus on "conceptual metaphors [that] consist of a source domain and a target domain" (Kövecses (2010, p. 17). In other words we "talk and, potentially, think about something in terms of something else" (Semino, 2008, p. 1). Kövecses (2010) stresses that "various studies have shown that second language learners can benefit significantly from activities that heighten their awareness of metaphor (and metonymy)" (p. 239). It seems absolutely fascinating to look at a text from a new, fresh perspective. What follows is an analysis of FOSSIL SKULL SHOWS SPLIT IN PRIMATE'S LINEAGE through the prism of metaphorical cohesion. An attempt has been made to single out those chunks which derive from conceptual metaphors (and metonymy).

Exercise 11. Single out those chunks which derive from the conceptual metaphors.

Table 1: Determining Basic Meanings of Lexical Units in FOSSIL SKULL SHOWS SPLIT IN PRIMATE'S LINEAGE

\begin{tabular}{ll}
\hline TARGET DOMAIN & \multicolumn{1}{c}{ SOURCE DOMAIN } \\
\hline A DISCOVERY & - the skull ... sheds light on \\
IS AN ENLIGHTEMENT & - the discovery illuminates a moment ... \\
& - the skull shows split in ... \\
\hline
\end{tabular}

\section{Conclusion}

In the paper there has been made an attempt to present a sample of seven highly sophisticated text analyses to be implemented into educational settings. The new reading activities in question highlight features of authentic texts whose coherence has no counterpart in pedagogic texts (Note 1). In the $21^{\text {st }}$ century there has been observed a tendency for scientific experiments to enter classrooms and initiate pupils' interest in various domains of knowledge. Equally, language teachers are also encouraged to 'attack' texts with more and more advanced teaching techniques which develop not only reading but also writing skills. It is strongly believed that the examples presented here can be thoroughly explored, and successfully exploited by practicing teachers in order to bring real benefit for themselves and their foreign language students. For instance, the sample of approaches may be a useful preliminary to more serious action research and consequently to more reflective teaching and learning, importance of which cannot be overestimated.

\section{References}

“Fossil skull shows split in primates' lineage.” (2010, July 23-29). The Guardian Weekly, 31.

Bąk, A. (2004). Teaching and Learning Reading Skills in the Secondary Context. Unpublished PhD Thesis. University of Warsaw, Poland.

Bolívar, A. (1998). The structure of newspaper editorials. In Coulthard, M. (Ed.). Advances in written Text Analysis, (pp 279-294). London and New York: Routledge.

Dakowska, M. (2005). Teaching English as a Foreign Language. A Guide for Professionals. Warszawa: Wydawnictwo Naukowe PWN.

Fries, P., H. (1998). On Theme, Rheme and discourse goals. In Coulthard, M. (Ed.). Advances in written Text Analysis, (pp. 229-249). London and New York: Routledge.

Harri-Augstein S., \& Thomas, L. F. (1996). Conversational investigations of reading: the self-organized learner and the text. In Alderson, J. C. \& Urquhart, A. H. (Eds.). Reading in a Foreign Language, (pp. 250- 280). London and New York: Longman.

Hatch, E. (1994). Discourse and Language Education. Cambridge: Cambridge University Press.

Hatch, E., \& Brown, C. (1998). Vocabulary, Semantics, and Language Education. Cambridge: Cambridge University Press. 
Hoey, M. (1998). Signaling in discourse: a functional analysis of a common discourse pattern in written and spoken English. In Coulthard, M. (Ed.). Advances in Written Text Analysis. London and New York: Routledge, 26-45.

Hoey, M., (1996). Patterns of Lexis in Text. Oxford: Oxford University Press.

Johns, T. (1998). The text and its message. In Coulthard, M. (Ed.). Advances in Written Text Analysis, (pp. 102- 116). London and New York: Routledge.

Kövecses, Z. (2010). Metaphor. Oxford: Oxford University Press.

Langhoff, D. (2010). Wiązania leksykalne: strategia czytania. Języki Obce w Szkole, 3, 111-120.

Mahon, J. E. (1999). Getting your sources right. What Aristotle didn't say. In Cameron, L. \& Low, G. (Eds.). Researching and Applying Metaphor, (pp. 69-80). Cambridge: Cambridge University Press. http://dx.doi.org/10.1017/CBO9781139524704.007

Makowska, M. (2010). "The miscue analysis in the third form of lower secondary school." A final project in English methodology course. The State School of Higher Education in Sandomierz, Poland.

Malmkjær K. (Ed.) (2010). The Routledge Linguistics Encyclopedia. (3 ${ }^{\text {rd }}$ edition). London and New York: Routledge.

McCarthy, M. (1995). Vocabulary. Oxford: Oxford University Press.

Rigg, P. (1998). The Miscue-ESL Project. In Carrel, P. L. Devine, J. \& Eskey, D. E. (Eds.), Interactive Approaches to Second Language Reading, (pp. 206-219). Cambridge: Cambridge University Press.

Semino, E. (2008). Metaphor in Discourse. Cambridge: Cambridge University Press.

Urbanowá, Z. (2007). Newspaper Report Discourse Pattern And Lexical Cohesion. In Machowá, P. \& Vraśtilová, O. (Eds.). Ways to Teaching and Learning. Association of Teachers of English of the Czech Republic, (pp. 137-143). Hradec Králové: Association of Teachers of English of the Czech Republic.

\section{Note}

Note 1. The examination of distribution patterns of cohesion in authentic and inauthentic English texts has revealed that "coursebook reading texts are shorter than articles included in English and American magazines [i.e. TIME AND NEWSWEEK]. ... Although texts from magazines are longer, they contain more empty cells and consequently they have loosely structured texture. Inauthentic texts, in reverse, have more one-repetition-ties as well as a slightly higher number of bonds" (Bąk, 2004, p. 166).

\section{APPENDIX 1}

\section{Fossil skull shows split in primates' lineage}

A fossilised skull has been unearthed that sheds light on the evolutionary origins of apes, including humans. The creature was no bigger than a baboon and lived in a warm, damp forest near what is now the Red Sea in western Saudi Arabia, between $28 \mathrm{~m}$ and $29 \mathrm{~m}$ years ago. The remains of the primate, named Saadanius hijazensis, which include a partial skull and teeth, were recovered from ironstone sediment during an expedition in February 2009. The discovery, reported in Nature, is being hailed as very significant because it illuminates a moment in evolution when ancient primates split into two separate lineages. One group of primates gave rise to the Old World monkeys, which include baboons, while the other led to the great apes and, ultimately, Homo sapiens. 